\title{
Conditioners of the infectious diseases dynamics
}

\section{Anderson Luiz Pena da Costa ${ }^{1}$, Orlando Alves Rodrigues Neto ${ }^{2}$ e Antonio Carlos Souza Silva-Júnior ${ }^{3}$}

\author{
1 Mestrando do Programa de Pós-Graduação em Ciências Farmacêuticas da Universidade Federal do Amapá, Brasil. \\ E-mail: pena.biologo@gmail.com (iD http://orcid.org/0000-0002-7876-0187 \\ 2 Acadêmico do curso de Farmácia do Instituto Macapaense do Melhor Ensino Superior, Brasil. \\ E-mail: orlandonetoof@gmail.com (iD) http://orcid.org/0000-0003-4599-4523
}

3 Biólogo e Mestre em Ciências da Saúde pela Universidade Federal do Amapá, pesquisador do Instituto de Pesquisas Científicas e Tecnológicas do Estado do Amapá, e docente do Colegiado de Farmácia do Instituto Macapaense do Melhor Ensino Superior, Brasil. E-mail: jr bio2005@yahoo.com.br (iD http://orcid.org/0000-0002-6921-9030

\begin{abstract}
The natural history of diseases is a concept in epidemiology that describes at the individual level the interaction of an individual with a disease stimulus, its clinical horizons, and transmission routes, which enable the identification of critical points for the prevention and control of infectious diseases. However, although this concept implies a dynamic process of exposure, contraction of disease, and cure or death, it does not provide an understanding of the dynamics of transmission of infectious agents at the population level in different scenarios, where anthropological, biological, clinical and social factors can act as conditioners for infectious diseases, that can manifest and transform in a variety of ways in different human populations. In this context, the objective of this work was to review the literature according to the Cooper (1988) methodology, to generate perspectives on the dynamics of infectious diseases, their conditioners and their interrelationship. It is demonstrated that environmental changes, pathogens evolution and host co-evolution, as well as behavioral and social set, influence significantly the epidemic events, and mathematical modeling represents an important tool to analyze this influence.
\end{abstract}

Keywords: Host-pathogen interaction. Infectious Diseases. Transmission dynamics. Epidemiology.

\section{Condicionantes da dinâmica das doenças infecciosas}

RESUMO: A história natural das doenças é um conceito em epidemiologia que descreve ao nível individual a interação de um indivíduo com um estímulo doença, seus horizontes clínicos e vias de transmissão, que possibilitam a identificação de pontos críticos para a prevenção e controle de doenças infecciosas. Entretanto, apesar de este conceito implicar um processo dinâmico da exposição, contração da doença, e cura ou morte, não possibilita uma compreensão sobre a dinâmica de transmissão de agentes infecciosas ao nível populacional em diferentes cenários, onde fatores antropológicos, biológicos, clínicos e sociais podem atuar como condicionantes das doenças infecciosas, que podem se manifestar e se transformarem das mais variadas formas nas populações humanas. Neste contexto, este trabalho teve como objetivo, por uma revisão da literatura realizada conforme a metodologia de Cooper (1988), gerar perspectivas sobre a dinâmica das doenças infecciosas, seus condicionantes e a suas inter-relações. Sendo demonstrado que as transformações ambientais, biológicas dos microrganismos e dos hospedeiros, assim como configurações comportamentais e sociais influenciam de forma significativa nos eventos epidêmicos, e a modelagem matemática representa uma im- 
portante ferramenta para analisar essa influência.

Palavras-chave: Interação patógeno-hospedeiro. Doenças infecciosas. Dinâmica de transmissão. Epidemiologia.

\section{INTRODUCTION}

Infectious diseases are diseases whose etiologies are attributed to external agents, usually microorganisms, that depend on a host to obtain nutrition and conditions favorable to its survival, being characteristic of this group of diseases, besides the communicability among individuals of the same species, the potential capacity to generate unpredictable massive impacts at the global level (FAUCl; MORENS, 2012).

And among the factors that influence the host-pathogen interaction, there are human behavior, environmental conditions and the intrinsic ability of infectious agents to evolve and co-evolve together with their hosts and vectors; however, such diseases possess the potential to be prevented and eradicated through prophylactic measures, vaccination, and treatment with appropriate drugs (SAKER; FAUCl; MORENS, 2012).

These characteristics can be exemplified in the course of history in many epidemic events such as bubonic plague and pneumonic plague respectively in antiquity and middle age (LIGON, 2006), influenza pandemics in 1918, 1957, 1968 and 2009 (SAUNDERS- HASTINGS, KREWSKI, 2016), tuberculosis from the antiquity to the present day (BARBERIS et al., 2017), and more recently, the EBOLA outbreaks of the African continent in 1975, 2000, 2007, 2013 and 2014, and in 1986 in the United States and 2008 in the Philippines (PANDEY et al., 2014; NA et al., 2014) Zika virus in the American continent during 2015-2017 (CO-
LÓN-GONZÁLES et al., 2017), and the HIV / AIDS at the global level, whose projections of deaths attributed to this virus by 2030 are 3.7 million (MATERERS, LONCAR, 2006).

In this context, the dynamics of transmission of infectious diseases and their interrelation with numerous variables of distinct nature, such as environmental, biological and social, that constitutes a topic of broad relevance due to the impacts of these diseases in public health, and especially for the planning of public policies, and health care programs prepared for the unexpected.

Therefore, considering the concern presented, this work aimed to introduce the reader to the factors that determine the movement of infectious diseases in the human populations, to promote insights that improve the elaboration of public health actions and health care services. Additionally, as recall the relevance of practices that promote the preservation of the environment and biodiversity, which carry out a critical role in maintaining the barrier of the species between sylvatic pathogens and humans (KEESING et al., 2010).

\section{MATERIAL AND METHODS}

This review literature followed the methodology described by Cooper (1988), and focused on concepts, literary reports and experimental data described in the bibliographical material that was collected in the Web of Science, PubMed and Scopus databases with the descriptors infectious diseases, infectious diseases, transmission 
dynamics, and SIR model; with the aim of generating perspectives on the theme: conditioners of the dynamics of infectious diseases from the central points discussed in the literature, which were organized in an expositive and comprehensive manner, with health professionals as target public.

A total of 95 studies were obtained with the descriptors above, and 55 were selected to compose this review after analysis conducted by the authors, who considered in each study the explicitness established in the relationship between infectious diseases and environmental, anthropological, biological, clinical and social determinants in order to include the workes in the review.

\section{LITERATURE REVIEW}

\subsection{A phenomenological perspective on infectious diseases}

Anthropological and archaeological studies suggest that the prehistoric humans were nomadic with hunting/collecting habits, living in small communities, which tended to suffer from infections whose pathogens occurred in both animals and humans, causing them diseases which could not trigger an adaptive immune response, therefore allowing them to full recovery or develop chronicity, enabling the existence of continuous cycles of infection among the susceptible individuals (WOLFE et al., 2007).

However, the communicable diseases just became a common problem after the establishment of fixed communities, due to the invention of agriculture and domestication of animals, that affected not just the cultural evolution of humankind, but also the emergence and evolution of new infectious diseases, and the accentuation of the existing ones prior to these anthropic practices (COCKBURN, 1971).

Thereby over the centuries, with the emergence and intensification of new commercial routes, as well as the advances in the nautical technology, enormous migratory flows between distinct geographic regions allowed the exchange of infectious diseases whose epidemiological profiles were endemic. And this effect of migration on infectious diseases can be demonstrated by archaeological and paleontological evidence, that indicates diseases like smallpox, measles, malaria, and typhoid have been introduced into the native American population by the European colonizers, who brought with them diseases of parasitic nature from the new world to the European continent (COCKBURN, 1971; DOBSON; CARPTER, 1996).

In this scenario, intense migratory flow, associated with a large and uncontrolled exploratory activity by ores and spices, increased population densities, social contact and environmental changes that affected the quality of life of human populations and their degree of interaction with wildlife; suggesting that in the course of human history many infectious diseases of the present have become emerging through the transgression of the species barrier in the past, occurring this process when a pathogen discovers an opportunity to infect a host other than the usual and establishes itself among the populations of this new host (PEDERSEN; DAVIES, 2010).

In this context, according to Wolfe et al. (2007), pathogens originated from places with a temperate climate, probably are the result of crossing the barrier of species from domestic animals and/or animals adapted to survive near humans (rodents) to hu- 
mans, in whom acted in the transmission cycle just as reservoir; however, because of the sedentary lifestyle, population density and level of interaction with wildlife, the considerable selective pressure from these factors over the biology of the pathogens have adapted them to adopt man as the definitive host.

Whereas infectious diseases originated in places with tropical climate harbor mostly vector-borne diseases, and are common among non-human primates, which act as source or reservoir of infection; also pointing that the abundance and diversity of both vectors and primates in tropical regions are intrinsically high, and the species barrier between non-human primates and human primates is considerably smaller (WOLFE et al., 2007), meaning that these pathogens can across the species barrier and settle into human communities more easily.

In addition to the migratory processes and interaction with wildlife, other factors that act as conditioners for the emergence and spread of new pathogens are environmental, such as biodiversity abundance and richness, climatic variability, and natural disasters, which together have a profound impact on the survival and reproductive capacity of vectors and pathogens, besides influencing food production and hygiene standards, that along with economic factors, tend to move the human populations in search of better living conditions, generally in a rural-urban sense (PATZ et al., 1996;CONFALONIER, 2003).

From the scenario described above, in a context of modernity resulted from urbanization and the beginning of the globalized world, improvements in the infrastructure and health services in large cities, as well as advances in medicine, like the discovery of anti-infectious agents and immunization, contributed to the emergence of a new epidemiological profile where chronic diseases became the primary cause of morbidity and mortality, a phenomenon known as epidemiological transition (DYE, 2014).

However, even after the establishment of an epidemiological transition, the ruralurban migratory flow, besides contributing substantially to demographic increases, also favors the spread of rural pathogens in the urban environment, also contributing to increases in the social disparities, such as place of residence, ethnicity, gender, and scholarly level, but principally disparities regarding aspects such as sanitation, hygiene and management of solid residues that generate huge health inequalities (ALIROL et al., 2011).

In addition to the factors mentioned, already considering contemporaneity, changes in the society, contemplating aspects of human behavior, socio-cultural and the media influence on the same, (XIAO et al., 2013) as for example, consumption habits, family size reduction, increased local and international mobility for different purposes, such as work, recreational, or cases of war refugees, processes of homophily, including acculturation and transculturation, prescription and non-rational use of antimicrobial medicines, use of illicit drugs, unsafe and promiscuous sexual practices, intensification of agriculture for food production, and increased susceptibility of individuals due to chronic disease or malnutrition (diets with poor nutrient content in wealthy countries and non-availability of food in poverty-stricken countries), are factors that contribute to the emergence and reemergence of pathogens in human popu- 
lations (GUSHULAK; MACPHERSON, 2004).

In this context, the average age of individuals in a population is a characteristic of great epidemiological value in the dynamics of communicable diseases, since extremes of age represent a risk for infectious diseases, especially in countries that have already undergone an epidemiological transition and are aging in a historical, socioeconomic and regional context of great difficulties, such as Brazil, whose estimates for 2030 and 2060 suggest that the elderly population will be of $18.6 \%$ and $33.7 \%$, respectiveIy (NEUMAN, ALBERTS, 2018), representing a hot spot with great potential for the emergence of infectious diseases, if the health needs of this part of the population are not adequately met.

In this scenario, the dissemination and adherence to the ideas promoted by antivaccination movements, especially among the parents of children, whether through questioning of efficacy-safety, inconsequential promotion of natural treatments, lacking scientific grounds, conspiracy theories or religious beliefs comprise factors which lead to unpredictable outbreaks due to the increase in the number of susceptible individuals over the years (GRASSLY; FRASER, 2006; OLPINSKI, 2012).

Ultimately, in this phenomenological perspective about the infectious diseases dynamics and their impacts on mankind, consideration must be given to the evolutionary capacity that the microorganisms themselves are subject to, whether at random or as an adaptive response to preventive actions, such as the bacterial resistance to antibiotics or the genic recombination after immunization campaigns(COHEN, 2000).

And as the adaptive capacity to the chal- lenges imposed to the survival of pathogenic and non-pathogenic microorganisms is an innate characteristic of these living organisms and represents a variable of unforeseeable and unsurpassable nature (SIETTOS; RUSSO, 2013; STOCKMANN et al., 2016), research regarding the dynamics, prevention, and treatment of infectious diseases must be continuous to assure a good public health state.

\subsection{Factors that influence the pathogen- host interaction}

The human population, from the beginning of its history, is daily exposed to a wide variety of microorganisms, with which an individual can interact through a process called infection, which occurs when a microorganism successfully crosses the innate immunity barriers, invades the deep tissues, proliferate in them, and colonizing the individual that becomes infected and then is called host (CASADEVALL; PIROFSKI, 2000).

And the interaction between the microorganism and its host may result in relationships which can be neutral (commensalism), beneficial (mutualism) or harmful, when the microorganism (pathogen) establishes a relation of parasitism with the host and cause tissue damage which gradually gives rise to systemic damages, resulting in clinical manifestations that together characterize an infectious disease, whose main attribute is direct or intermediary communicability between infected and noninfected individuals (CASADEVALL; PIROFSKI, 2000; TAYLOR et al., 2001).

However, for the disease to establish, the defenses and physiological mechanisms that guarantee the host homeostatic balance must be disturbed in a way hard to 
reverse, that requires from the pathogen the capacities of resist to the physical and chemical properties intrinsic to the host tissues, as wells as overcome its innate and adaptive defense barriers, through sophisticated virulence mechanisms, and then establish relations with the host microbiota, by executing strategies to ensure its survival in the host and consequently initiating the pathogenesis process (EISENREICH et al., 2010; STACY et al., 2016).

Virulence mechanisms are intrinsic characteristics of each pathogenic microorganism, being the most common among bacteria, the presence of capsule, exotoxins, endotoxins, formation of biofilms, adhesion factors and enzymes that degrade the host cell matrices (CROSS, 2008; AL-MEBAIRIK et al., 2016); among fungi, dimorphism, thermotolerance, adhesion molecules, cell wall components, capsules, hydrolytic enzymes, suppression of cytokine production, and the presence of hormone receptors that alter fungal metabolism and host physiology (KUROKAWA et al., 1998); among parasites, the suppression of the adaptive immunity by means of glycoconjugate proteins, and the release of vesicles containing molecules essential for the establishment of infection in the host (TORRECILHAS et al., 2012); and among viruses, the expression of cytokine coding genes (IL-10), resistance genes against interferons, genes encoding endothelial growth factor, metabolic, signaling and cell cycle regulatory genes, among others (ZHANG et al., 2014) .

While the mechanisms of microbial pathogenesis, in a generic way, can be classified into three categories: 1 ) subversion or defeat of the innate host defenses, such as masking the cell surface of the fungus Histoplasma capsulatum against host defense cells, the induction of the host cells to death, as in the case of the release of proteins produced by Yersinia pseudotuberculosis that induces to apoptosis or pyroptosis, or the induction of the host cell death by toxins, such as those produced by the bacterium Bacillus anthracis; 2) creation of permissive niches for replication, such as, the proliferation of Salmonella within macrophages; or 3) development of antigenic variations to escape the mechanisms of recognition of the host's adaptive defense (CARRUTHERS et al., 2007).

On the other side, the evolution of the mechanisms of virulence and microbial pathogenesis, induce the co-evolution of the human populations, that began to develop several phenotypic traits of resistance against microbial pathogens, to prevent the infection to occur, or that the disease undergoes a relatively mild course when compared to the clinical manifestations in individuals of greater susceptibility (WOLFE et al., 2007). Occurring this reciprocal evolution in cycles, which through natural selection, maintain the relative fitness of the involved species in a constant dynamics, known as the hypothesis of the red queen (STOCKMANN et al., 2016).

Regarding the resistance factors against infectious diseases in humans, epidemiological evidence with broad genomic association studies suggests that individuals with sickle cell trait are resistant against Plasmodium falciparum infection; individuals in the Indian population with variants of the TLR1 gene are resistant to Mycobacterium leprae, differently from individuals from the European and Chinese populations, who are highly susceptible to leprosy; individuals with Wilms tumor type 1-associated genes possess significant resistance to Mycobacte- 
rium tuberculosis infection; and individuals with the CCR5 $\Delta$ variant 32 of the cell surface CCR5 receptor gene, have resistance to HIV infection when in the homozygous condition (KARLSSON et al., 2014).

Among the susceptibility factors, broad genomic association studies and epidemiological evidence suggest that individuals with type $\mathrm{O}$ blood are at elevated risk to develop severe Vibrio cholerae infection (KARLSSON et al., 2014), probably due to the higher affinity of the cholera toxin to the GM1 cell surface gangliosides, which interestingly do not act as receptors for this toxin, and the higher activity of the adenylate cyclase enzyme in the carriers of the blood type $\mathrm{O}$, when compared to the other types of the OAB system (HARRIS; LAROCQUE, 2016).

However, the disease as a result of pathogen-host interaction is interdependent of many dynamic factors involving variables that go beyond the intrinsic biological aspects of the pathogen and factors of resistance, susceptibility, and adaptability of the host, also including factors such as exposure profile to pathogen, transmission mechanisms and the influence of environmental, behavioral, cultural, political, and socioeconomic factors, which may play a determinant role in the incidence, prevalence and prevention of infectious diseases at the population level (PARRATT et al., 2016).

\subsection{A mathematical approach to the dy- namics of infectious diseases}

From an ecological perspective, the dynamics of infectious diseases depend on the following factors: the size and spatial distribution of susceptible host populations, the movement of infected/susceptible individuals, as well as the movement of vectors in the case of vector-borne diseases, and the state of the population health (DOBSON, CARPER, 1996), where the epidemiological significance of a particular infectious agent within this context can be expressed in values of $\mathrm{RO}$ (basic reproductive number of infection), which is a threshold quantity that defines the average number of secondary cases produced from a single infected individual (index case) within a susceptible population (DRIESSCHE, 2017).

For the determination of the RO values of a given infectious disease, the generation distribution of an infection, which is a mathematical property of the infectious diseases which describes the probability of an infected individual transmitting the pathogen to an uninfected individual (expressed according to equation 1), and the time of generation of an infection (equation $2)$, which describes the probability of an infected individual contracting the disease and transmitting the pathogen to other susceptible individuals must be considered in a way that the number of individuals that will be infected obeys the Poisson distribution, that is, the probability that an infection will occur regardless of when the last infection occurred (equation 3), and for simplicity, considering that all case numbers by time interval $(\tau)$ must be added, it becomes practical to integrate the second term of equation 3 , to estimate the number of infected individuals, generating the renewal equation (equation 4) (GRASSLY; FRASER, 2008).

Equation 1: Distribution of generations of infection.

$$
E(Y)=s \int_{0}^{\infty} \beta(\tau) d \tau=\mathrm{R}
$$


$E(Y)=$ Number of generations

$\mathrm{s}=$ susceptible population

$\beta=$ infectivity

$\beta(\tau)=$ function of the number of secondary infections from the index case

$\tau=$ number of cases / time

$Y=$ number of expected generations

$\mathrm{R}=$ reproduction number of an infection

Equation 2: Time of generation of an infection.

$$
w(\tau)=\beta(\tau) / R
$$

$w=$ generation time distribution

Equation 3: Stochastic probability of occurrence of infections.

$$
I(u) \beta(\tau)=I(t-\tau) \beta \delta \tau
$$

$I(u)=$ incidence function by time

$\mathrm{t}=$ time

$\delta \tau=$ duration of a time interval

Equation 4: Equation of renewal.

$$
I(t)=\int_{0}^{\infty} I(t-\tau) \beta(\tau) d \tau
$$

In that the relation of infectivity $(\beta)$ and time of distribution that the relation of infectivity $(\beta)$ and time of distribution, when substituted in equation 4 , generates an equation capable of providing an estimate of the reproduction number of a given infection as a function of time ( $(\mathrm{t}))$, according to equation 5 below:
Equation 5: Estimation of the number of infection as a function of time.

$$
R(t)=\frac{I(t)}{\int_{0}^{\infty} I(t-\tau) w(\tau) d \tau}
$$

However, the value of $R(t)$ assumes there is no change in the value of time of generation of an infection, and adjustments become necessary to correct this undesirable effect, by using an exponential growth function - rl (t0) exp ( $r$ ( t-t0) - in which equation 4 that enables the obtaining of a new equation called the Lotka-Euler estimation equation (equation 6) that provides important informations about the relation between $\mathrm{RO}$ and $r$ for a given time of generation of an infection, which has a great value for the elaboration and development of predictive and infectious disease control mathematical models (GRASSLY; FRASER, 2008), as the statistical-based models, the mechanistic models, and the empirical models (SIETTOS, RUSSO, 2013).

Equation 6: Lotka-Euler's estimation equation.

$$
R 0=\frac{1}{\int_{0}^{\infty} W(\tau) e^{-r t} d t}
$$

Where values of R0> 1 indicate a considerable predictive risk of epidemic events, while values of $\mathrm{R} 0<1$ indicate a low risk for the occurrence of epidemic events, and informing the ideal amount of individuals in the population to be approached by control strategies in order to be effective by reaching the value of 1- (1 / RO) (KEELING; DANON, 2009; COOPER et al., 2012, CHEN et al., 2016; DRIESSCHE, 2017).

Highlighting that RO values imply a dy- 
namic parameter of a specific infectious disease, and its values are restricted to the time and space where the RO is calculated.

Examples of infectious diseases with values above 1 include Bordetella pertussis (pertussis) infection in southern Ontario, Canada, where the infection reached RO between 9.87 and 11.47 for the years 1880 to 1929 (MCGIRR et al., 2013); methicillinresistant Staphylococcus aureus and methicillin-sensitive Staphylococcus aureus infections in the US population, which respectively presented values of RO of 1,5 and 1.4 (HOGEAC et al., 2013); Vibrio cholerae infections in countries with similar climatic and sociopolitical conditions, which may present different RO values, such as 1.55 in Haiti and 1.15 in Zimbabwe, with variation recorded respectively of 1.06 to a 2,63 and 1,11 to 2,72 (MUKANDAVIRE; JUNIOR, 2013), And tuberculosis in China during 2012, when R0 values of 4.3 were reported (MA et al., 2018).

In addition, another complementary mathematical strategy to extrapolate the epidemiological behavior of infectious diseases in a given population is the use of mathematical models, such as the SIR model (susceptible, infected and recovered), which is a mathematical model that implies a homogeneous mixture of contact and total conservation of the population in an analogous way to the law of conservation of the masses, assuming transitoriness between the categories S, I and R, defining the model as continuous in the form of differential (equation 7) and or partial equations, which can be used as a tool for the investigation of several parameters (characteristics of the host population, vectors, quarantine, and others) on the dynamics of infectious diseases (SIETTOS, RUSSO, 2013).
Equation 7: Differential equations of the SIR model.

Total population $=\mathrm{S}+\mathrm{I}+\mathrm{R}$, where:

$$
\begin{gathered}
S=\frac{d S}{d T}=-\beta S I \\
I=\frac{d I}{d t}=\beta S I \\
R=\frac{d R}{d t}=\gamma I
\end{gathered}
$$

$\mathrm{S}=$ susceptible population

$\mathrm{I}=$ infected population

$\mathrm{R}=$ population recovered

$\beta=$ proportionality constant for infection

$\gamma=$ recovery rate

However, this is not a realistic strategy, analyses of the epidemiological behavior of infectious diseases that consider only the population densities of S, I and R over time neglect the influence of other variables such as mutations of the pathogen that increase their virulence, death saturation or adaptive host immunity (GRASSLY; FRASER, 2008), and the intrinsic latency period of the infection make inaccurate the description of the dynamics of infections in a susceptible population (LINDAHL, GRACE, 2015, DRIESSCHE, 2017).

But in a generic way, the SIR model captures the essence of infectious diseases in which it is possible to observe graphically (figure 1) that the number of infected individuals increases exponentially and proportionally with the decrease in the number of susceptible individuals, and the number of infected individuals decreases as the number of recovered individuals increase (KEELING; DANON., 2009). 
Figure 1: Graphic representation of the SIR mathematical model of infectious diseases.

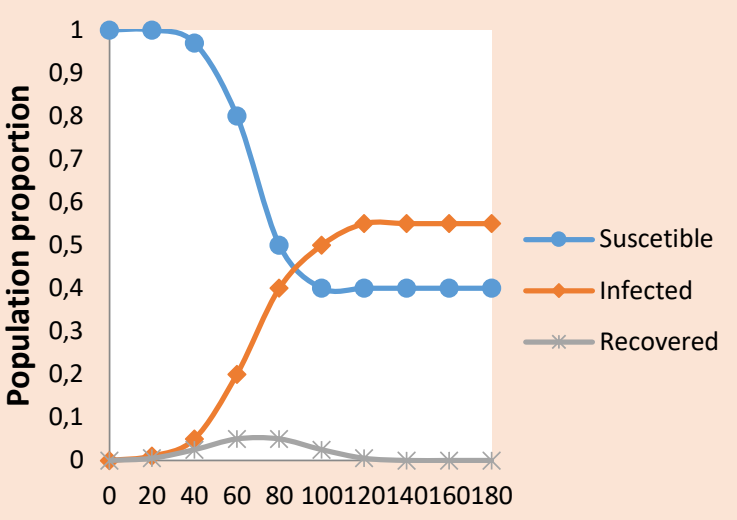

Time (days)

Source: The author (2018), adapted from (KEELING; DANON., 2009)

Other factors that are generally disregarded in the mechanistic modeling, but considering its effects on the dynamics of infectious diseases, would give it a higher degree of realism, are the climatic variability (CONFALONIERI, 2003), profile of social heterogeneity, as well as social contact rate, age of the population, and the relation between both (principle of assortativity: individuals of a given age group tend to mix with individuals of a similar age) (HEYMANN, 2005; FUMANELLI et al., 2012; VANHEMS et al., 2013), period of exposure of social groups of the susceptible population to the pathogen (MUKANDAVIRE, JUNIOR, 2015), including risk factors, peculiar aspects of the natural history of each infectious disease, pathogenesis mechanism, sources of infection, pathogen reservoirs, patterns of transmission and circulation (EYBPOOSH et al., 2017; HERFST et al., 2017).

Nonetheless, the simplicity of the SIR model, like any other mathematical models, it is a tool extremely effective for planning public health actions in the "worst-case" context considering the qualitative behavior of infectious disease dynamics (ZAMAN et al., 2017).

\section{CONCLUSIONS}

Historically, the infectious diseases have been the main cause of morbidity and mortality worldwide, and a significant epidemiological transition has only occurred after the adoption of hygienic and prophylaxis measures more rigid due to the advent of food preservation and sanitation techniques, as well as the discovery of effective drugs to the treatment of these diseases.

However, the interaction between the human populations and the environment is subject to a perpetual movement of changes, which influence the intensity of exposure to infectious agents, as well as the dissemination of microbial pathogens at the population level due to factors of environmental, biological and socio-anthropological natures, which together act as conditioner factors in the transmission dynamics of infectious diseases, that along with the health inequalities around the world impose a great impact on the global public health.

What makes extremely important the integration between anthropologists, biologists, environmental scientists, nurses, epidemiologists, pharmacists, physicians and sociologists with mathematicians and computer scientists essential for the rational planning and development of prophylactic interventions and treatment schemes through a broad understanding of the factors that condition the dynamics of infectious diseases, and its implementation to mathematical models to describe in details the epidemiological features of these diseases.

In this scenario, attention also should be 
given to the media communication professionals in order to better create and disseminate information effective in reducing exposure to risk factors and promote the rational adhesion to pharmacological treatments within the different spheres of society, since human behavior is a factor that exerts great influence over the other factors, and is also one of the most difficult to isolate and study, besides representing a subject to major transformations with the progression of time.

And regarding the evolutionary processes of pathogens, their origins lie mainly in the selective pressures exerted by antimicrobial treatments and immunization, which reaffirms the need for implementation of the professionals mentioned above in the current epidemiology and in the promotion of the rational use of vaccines and pharmaceutical resources, as well as in the design of studies aiming to obtain greater clarity about the evolutionary dynamics of the infectious agents.

\section{REFERENCES}

ALIROL, E.; GETAZ, L.; STOLL, B.; CHAPPUIS, F.; LOUTAN, L. Urbanization and infectious diseases in a globalized world. Infection, $v$. 11, p. 131-141, 2011. https://doi.org/10. 1016/S1473-3099(10)70223-1

AL-MEBAIRIK, N.F.; EL-KERSH, T.A.; ALSHEIKH, Y.A.; MARIE, M.A.M. Review of virulence factor, pathogenesis, and antibiotic resistance in Staphylococcus aureus. Review in Medical Microbiology, v.27, p. 50-56, 2016. https://doi.org/10.1097/MRM. 0000000000000067

BARBERIS, I.; BRAGAZZI, N.L.; GALLUZO, L.; MARTINI, M. The history of tuberculosis: From the first historical records to the isola- tion of koch's bacillus, Journal of preventive medicine and hygiene, v. 58, p. 9,12, 2017.

CASADEVAlL, A.; PIROFSKI, L. A. Hostpathogen interactions: Basic concepts of microbial commensalism, colonization, infection, and disease. Infection and Immunity, v. 68, n. 12, p. 6511-6518, 2000. https://doi.org/10.1128/IAl.68.12.6511-

6518.2000

CARRUTHERS, V.B.; COTTER, P.A.; JUMAMOTO, C.A. Microbial Pathogenesis: Mechanisms of Infectious disease. Cell Host Microbe, v.2, n.4, p.214-219, 2007. https:// doi.org/10.1016/i.chom.2007.09.007

CHEN, S.; SANDERSON, M.W.; LEE, C.; CERNICCHIARON, N.; RENTER, D.G.; LANZAS, C. Basic reproduction number and transmission dynamics of common serogroups of enterohemorrhagic Escherichia coli. Applied and environmental microbiology, v. 82, n. 18, p. 5612-5620, 2016. https://doi.org/10.1128/AEM.00815-16

COCKBURN, A. Infectious diseases in ancient populations. Current Antropology, v. 12 , n. 1, p. 45-62, 1971. https://doi.org/10. $\underline{1086 / 201168}$

COHEN, M.L.; Changing patterns of infectious diseases. Nature, v. 406, p. 762-767, 2000. https://doi.org/10.1038/35021206 COOPER, H.M. Organizing knowledge synthesis: A taxonomy of literature reviews. Knowledge in Society. v.1, n.1, p. 104-126, 1988. https://doi.org/10.1007/BF03177550 COOPER, B.S.; KYPRAIOS, T.; BATRA, R.; WYNCOLL, D. TOSAS O; EDGEWORTH, J.D. Quantifying type-specific reproduction numbers for nosocomial pathogens: Evidence for heightened transmission of an Asian sequence type 239 MRSA clone. Plos Computational biology, v. 8 , n. 4, p. 1-13, 2012. https://doi.org/10.1371/journal.pcbi. 
1002454

COLÓN-GONZÁLES, F.J.; PERES, C.A.; SÃO BERNARDO, C.S.; HUNTER, P.R.; LAKE, I.R. After the epidemic: Zika virus projections for Latin America and the Caribbean, Plos Neglected Tropical Diseases, v. 11, n.11, p. 1-19, 2017. https://doi.org/10.1371/jour nal.pntd.0006007

CONFALONIER, U.E.C. Variabilidade climática, vulnerabilidade social e saúde no Brasil, Terra livre, v.1, n.9, p. 193-204, 2003.

CROSS, A.S. What is a virulence factor? Critical care, v.12, n, 6, p.1-2, 2008. https://doi. org/10.1186/cc7127

DOBSON, A.P.; CARPER, E.R. Infectious diseases and human population history, Bioscience, v.46, n. 2, p, 115-127, 1996. https: /doi.org/10.2307/1312814

DRIESSCHE, P.D Reproduction number of infectious diseases models. Infectious Disease Modelling, v. 2, p. 288-303, 2017. https://doi.org/10.1016/j.idm.2017.06.002

DYE, C. After 2015: Infectious diseases in a new era of health and development. Philosophical Transitions of the Royal B Society, v. 369, p. 1-9, 2014. https://doi.org/10. 1098/rstb.2013.0426

EISENREICH, W.; DANDEKAR, T.; HEESEMANN, J.; GOEBEL, W. Carbon metabolism of intracellular bacterial pathogens and possible links to virulence. Nature Reviews Microbiology, v.8, p. 401-412, 2010. https: //doi.org/10.1038/nrmicro2351

EYBPOOSH, S.; HAGHAOOST, A.A.; MOSTAFAVI, E.; BAHRAMPOUR, A.; AZADMANESH, H.K.; ZOLLALA, F.; Molecular epidemiology of infectious diseases, Physician, v.9, n.8, p, 5149-5158, 2017. https://doi.org/10.19082/ 5149

FAUCI, A.S.; MORENS, D.M. The perpetual challenge of infectious diseases, The New England Journal of Medicine, v. 366, p. 454-
461, 2012. https://doi.org/10.1056/NEJMra 1108296

FUMANELLI, L.; AJELLI, M.; MANFREDI, P.; VESPIGNANI, A.; MERLER, S. Inferring the structure of social contacts from demographic data in the analysis of infectious diseases spread. Plos computational biology, v. 8, n. 9, p. 1-10, 2012. https://doi.org/ 10.1371/journal.pcbi.1002673

GRASSLY, N.C.; FRASER, C. Seasonal infections disease epidemiology. Proceedings of the Royal Society B, v.272, p. 2541-2550, 2006. https://doi.org/10.1098/rspb.2006. 3604

GRASSLY, N.C.; FRASER, C. Mathematical models of infectious diseases transmission, Nature Reviews Microbiology, v.6, p. 477487, 2008. https://doi.org/10.1038/nrmicro 1845

GUSHULAK, B.D.; MACPHERSON, D.W. Globalization of infectious diseases: the impact of migration. Travel Medicine, v. 32, p. 1742-1748, 2004. https://doi.org/10.1086/ 421268

HARRIS, J.B.; LAROCQUE, R.C. Cholera and $A B O$ blood group: Understanding an ancient association. American Journal of Tropical Medicine and Hygiene, v.95, n. 2, p. 263264, 2016. https://doi.org/10.4269/ajtmh. 16-0440

HEYMANN, D.L. Social, behavioral and environmental factors and their impact on infectious diseases outbreak. Journal of Public Health Policy, v. 26, p. 133-139, 2005. https://doi.org/10.1057/palgrave.jphp.3200 $\underline{004}$

HOGEA, C.; VAN EFFELTERRE, T.; ACOSTA, C.J. A basic dynamic transmission model of Staphylococcus aureus in the US population. Epidemiology Infection, v. 142, p. 468-478, 2013. https://doi.org/10.1017/S095026881 $\underline{3001106}$

https://periodicos.unifap.br/index.php/estacao Macapá, v. 8, n. 3, p. 09-23, Sept./Dec. 2018 
HERFST, S.; BÖHRINGER, M.; KARO, B.; LAWRENCE, P.; LEWIS, N.S.; MINA, M.J.; STEEL, J.; SWART, R.L.; MENGE, C.M. Drivers of airborne human-to-human pathogen transmission. Current opinion in Virology, v. 22, p. 22-29, 2017. https://doi.org/10. 1016/i.coviro.2016.11.006

KARLSSON, E.K.; KWIATKOWSKI, D.P.; SABETI, P.C. Natural selection and infectious diseases in human populations. Nature Reviews Genetics, v. 15, p. 379-393, 2014. https://doi.org/10.1038/nrg3734

KEELING, M.J.; DANON, L. Mathematical modelling of infectious diseases. British medical bulletin, v. 92, p. 33-42, 2009. https://doi.org/10.1093/bmb/ldp038

KEESING, F.; BELDEN, L.K.; DASZAK, P.; DOBSON, A.; HARVEL, C.D.; HOLT, R.D.; HUDSON, P.; JOLLES, A.; JONES, K.E.; MITCHELL, C.;E.; MYERS, S.S.; BOGICH, T.; OSTFELD, R.S. Impact of biodiversity on the emergence and transmission of infectious diseases, Nature, v. 468, p. 647-652, 2010. https://doi.org/10.1038/nature09575

KUROKAWA, C.S.; SUGIZAK, M.F.; PERAÇOLI, M.T.S. Virulence factors in fungi of systemic mycoses. Revista do Instituto de Medicina Tropical de São Paulo, v.40, n. 3, p. 125135, 1998. https://doi.org/10.1590/S003646651998000300001

LINDAHL, J.F.; GRACE, D. The consequences of human actions on risk factors for infectious diseases: a review. Infection Ecology and Epidemiology, v. 5, p. 1-11, 2015. https://doi.org/10.3402/iee.v5.30048

LIGON, B.L. Plague: A review of its history and potential as a biological weapon, Seminars in pediatric infectious diseases, v. 17, p. 161-170, 2006. https://doi.org/10.1053/j. spid.2006.07.002

MA, Y.; HORSBURGH, C.G.; WHITE, L.F.; JENKISN, H.E. Quantifying TB transmission: a systematic review of reproduction number and serial interval for tuberculosis. Epidemiology and Infection, p. 1-7, 2018. http s://doi.org/10.1017/s095268818001760

MATHERS, C.D.; LONCAR, D. Projections of global mortality and burden of disease from 2002 to 2030, Plos Medicine, v.3, n.11, p. 2011- 2030, 2006. https://doi.org/10.1371/ journal.pmed.0030442

MCGIRR, A.A.; TUITE, A.R.; FISMAN, D.N. Estimation of the underlying burden of pertussis in adolescent and adults in southern Ontario, Canada. Plos one, v. 8, n. 12, p. 18, 2013. https://doi.org/10.1371/journal. pone. 0083850

MUKANDAVIRE, Z.; JUNIOR, J.G.M. Modeling the epidemiology of cholera to prevent disease transmission in developing countries, Microbial Spectr. v.3, n.3, p. 1-10, 2015. https://doi.org/10.1128/microbiolspe c.VE-0011-2014

NA, W.; PARK, N.; YEOM, M.; SONG, D. Ebola outbreak in western Africa 2014: What is going on with Ebola virus? Clinical and experimental vaccine research, v. 4, p. 17-22, 2014. https://doi.org/10.7774/cevr.2015.4. $\underline{1.17}$

NEUMANN, L.T.V.; ALBERT, S.M. Aging in Brazil. The Gerontologist, v. 0, n. 0, p. 1-7, 2018. https://doi.org/10.1093/geront/gny0 $\underline{19}$

OLPINSKI, M. Anti-vaccination movement and parental refusal of immunization of children in USA. PediatriaPolska, v.87, p. 381-385, 2012. https://doi.org/10.1016/i.pe po.2012.05.003

PANDEY, A.; ATKINS, K.E.; MEDLOCK, J.; WENZEL, N.; TOWNSEND, J.P.; CHILDS, J.E.; NYENSWAH, T.G.; NDEFFO-MBAH, M.L.; GALVANI, A.P. Strategies for containing Ebola in west Africa, Science, v. 346, n. 6212, p. 991-995, 2014. https://doi.org/10. 


\section{6/science.1260612}

PARRATT, S. R.; NUMMINEN, E.; LAINE, A.-L. Infectious Disease Dynamics in Heterogeneous Landscapes. Annual Review of Ecology, Evolution, and Systematics, v. 47, n. 1, p. 283-306, 2016. https://doi.org/10. 1146/annurev-ecolsys-121415-032321

PATZ, J.A.; EPSTEIN, P.R.; BURKE, T.A.; BALBUS, J.M. Global climate change and emerging infectious diseases, JAMA, v.275, n.3, p. 217-223, 1996. https://doi.org/10.1001/ jama.275.3.217

PEDERSEN, A.B.; DAVIES, T.J. Cross-speceis pathogens transmission and disease emergence in primates. Eco Health, p.1-13, 2010. SAKER., L. S.; LEE, K.; CANNITO, B.; CAMPBELL-LENDRUM, D. Globalization and Infectious diseases: a review of the linkages. UNICEF/UNDP/WORLD BANK/WHO Special Program for Research and Training in Tropical Diseases, n. 3, p. 1-62, 2004.

SAUNDERS-HASTING, P.R.; KREWSKI, D. Reviewing the history of pandemic influenza: Understanding patterns of emergence and transmission, Pathogens, v. 5, n. 66, p. 1-19, 2016. https://doi.org/10.3390/pathogens50 $\underline{40066}$

STACY, A.; MCNALLY, L.; DARCH, S.E.; BROWN, S.P.; WHITELEY, M. The biogeography of polymicrobial infection. Nature Reviews Microbiology, v.16, p. 93-105, 2016. https://doi.org/10.1038/nrmicro.201 $\underline{5.8}$

SIETTOS, C.I.; RUSSO, L. Mathematical modelling of infectious diseases. Virulence, v. 4, n. 4, p. 295-306, 2013. https://doi.org/10. 4161/viru.24041

STOCKMANN, C.; AMPOFO, K.; PAVIA, A.T.; BLASCHE, A.J.; MASON, E.O.; PRESSON, A.P.; FORNEY, L.J.; BYINGTON, C.L. Clinical and epidemiological evidences of the red queen hypothesis in pneumococcal serotype dy- namics, Clinical Infectious Diseases, v. 63, n. 5, p. 619-626, 2016. https://doi.org/10. 1093/cid/ciw357

TAYLOR, L.H; LATHAM, S.M.; WOOLHOUSE, J. Risk factors for human disease emergence. Philosophical transitions Royal Society London B, v. 356, p. 983-989, 2001. https://doi.org/10.1098/rstb.2001.0888

TORRECILHAS, A.C.; SCHUMACHER, R.I.; ALVES, M.J.M.; COLLI W. Vesicles as carries of virulence factors in parasitic protozoan disease, Microbes and Infection, v.14, n.15, p. 1465-1474, 2012. https://doi.org/10. 1016/i.micinf.2012.07.008

VANHEMS, P.; BARRAT, A.; CATTUTO, C.; PINTON, J.F.; KHANAFER, N.; RÉGIS, C.; KIM, B.; COMTE, B.; VOIRIN, N. Estimating potential infection transmission routes in hospital wards using wearable proximity sensors. Plos One, v.8, n. 9, p. 1-12, 2013. https:// doi.org/10.1371/annotation/b20d3cec-62b 7-44ec-9150-8a06a9b30a9b

XIAO, Y.; ZHAO, T.; TANG, S. Dynamics of an infectious diseases with media/psychological induced non-smooth incidence, Mathematical Biosciences and Engineering, v. 10, n. 2, p. 445-461, 2013. https://doi.org/10.3934/mbe.2013.10.445 ZAMAN, G.; JUNG, I.H.; TORRES, D.F.M.; ZEB, A. Mathematical modelling and control of infectious diseases, Computational and mathematical methods in medicine, article ID 7149154, p.1, 2017. https://doi.org/10. 1155/2017/7149154

ZHANG, K.; LIU, Y.; SHANG, Y.; LIU, X.; CAI, $X$. Major virulence factors of Orf virus and their mechanism for immune evasion, Austin Journal of Infectious Diseases, v.1, n.1, p. 1-5, 2014.

WOLFE, N.D.; DUNAVAN, C.P.; DIAMOND, J. Origin of major human infectious diseases. Nature, v.447, p. 279-283, 2007. https:// 


\section{doi.org/10.1038/nature05775}

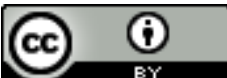

License information: This is an openaccess article distributed under the terms of the Creative Commons Attribution License, which permits unrestricted use, distribution, and reproduction in any medium, provided the original work is properly cited.

Article received on June 03, 2019.

Evaluated July 26,2019.

Accepted on August 05, 2019.

Published on August 07, 2019.

\section{How cite this article (ABNT):}

COSTA, Anderson Luiz Pena da; RODRIGUES NETO, Orlando Alves; SILVA-JÚNIOR, Antonio Carlos Souza. Conditioners of the infectious diseases dynamics. Estação Científica (UNIFAP), Macapá, v. 8, n. 3, p. 09-23, Sept./Dec. 2018. 